\title{
Cost of Cultivation of Mustard crop in Fatehpur District of Uttar Pradesh
}

\author{
Praveen Kumar Sahu*, Krishna Kant, Harendra Pratap Singh Choudhri and \\ G.P. Singh \\ Dept. of Agricultural Economics N.D. University of Agriculture \& Technology, Kumarganj, \\ Faizabad-224 229 (U.P.) India \\ *Corresnonding author
}

\section{A B S T R A C T}

Mustard become an essential oilseeds crop with its positive nature of suitability to climatic condition for its cultivation, being an important cooking medium according to the test of human diet and having various industrial uses of its main and by product. Since it is a low cost and high price crop can be cultivated in water stress and low soil fertility condition, mustard become a nice alternative to the farmers in place of wheat in rabi season crops.

Keywords

Cost of cultivation, Mustard, Fatehpur, Personal interview

\section{Article Info}

Accepted: 20 July 2018 Available Online: 10 August 2018
Keeping in view the importance of the crop a study on Economics of production of mustard was conducted in dist. Fatehpur Uttar Pradesh. One hundred respondents were selected through purposive cum proportionate random sampling technique from five villages of Hathgam block of Fatehpur district. Personal interview was done on prestructured schedule for primary data collection. Tabular and functional analyses were used to draw the inferences. Respondents were categorised as marginal, small and medium size of farm. Costs of cultivation were increases with farm size, highest cost incurred in the production of mustard was found in medium farm size Rs.32555.94, per ha. and highest share of cultivation of mustard was human labour Rs. 8870.95, per ha. and overall cost of cultivation of mustard crop was Rs. 30448.01 per ha. and maximum share in cultivation of human labour Rs. 8613.84 per ha. On overall average, gross income was recorded Rs. 43994.73 and net income came to Rs.13847.75. On marginal farms, gross income was highest, which was recorded Rs.44173.71, followed respectively. On an average input output ratio the basis costs $\mathrm{A}_{1} / \mathrm{A}_{2}, \mathrm{~B}_{1}, \mathrm{C}_{1}, \mathrm{C}_{2}$ and $\mathrm{C}_{3}$ were recorded 1:3.06, 1:2.96, 1:2.06, $1: 2.07,1: 1.58$ and $1: 1.44$, respectively At last mustard cultivation was found profitable and showed the further increase in profit per unit of time and area if the constraints of production and marketing is solved.

\section{Introduction}

India is one of the fourth major players in the vegetable oil scenario of the world, being one of the important oilseed growers, importer and exporter. Among the nine oilseed crops grown in the country have supported commercial cultivation of seven annual edible crops (soybean, groundnut, rapeseed-mustard, sunflower, sesame, safflower and niger) and two are of non-edible oils (castor and linseed). Besides a number of minor oilseeds of horticultural and forest origin including in particular coconut and oil palm. There has been a continuous improvement in the production and productivity of oilseeds in 
India in the last 55 years, There has been more than five times increase in oilseeds production during the period 1950 to 2005 and 2.5 times increases since 1986 under predominantly rainfed agro-ecological conditions. Overall during 1986-2004, the production of oilseeds grew at the rate of 2.84 per cent per annum along with productivity growth of 1.95 per cent and the area growth of 0.84 per cent. India is the largest producer of oilseeds in the world and accounts for about 14 per cent of the global oilseeds area, $7 \%$ of the total vegetable oil production, and $10 \%$ of the total edible oils consumption. Major consuming states of rapeseed-mustard oil in India are: Gujarat, Maharashtra, Rajasthan and Madhya Pradesh accounting 9\%, Delhi, Punjab, J\&K, Himachal Pradesh and UP accounting 25\% and East West Bengal, Orissa, Bihar, Assam, Chhattisgarh, Jharkhand accounting about 30\%. Oilseeds accounts for $3 \%$ to the Growth of National Products and $10 \%$ to the total value of all agricultural products, and employs 14 and 1 million people respectively. In 2012-13, the total oilseed cultivated area, the total oilseed seed production and the total edible oil production, respectively, were 27 million ha, 29 million matric tones (mmt) and $7.45 \mathrm{mmt}$. Presently, India's annual edible oil consumption is about $17.5 \mathrm{mmt}$, which in the last decade has increased steadily at a compounded annual growth rate of $4.6 \%$. The growth in per capita consumption is attributable to both rising income levels and living standards. However, the current per capita consumption of $14.3 \mathrm{~kg} /$ year in 2012 13 in India is considerably lower than the global average of $24 \mathrm{~kg} / \mathrm{year}$. In 2012-13, the major edible oils consumed in the country are palm oil, soybean oil and mustard oil, with their respective shares of $46 \%, 16 \%$ and $12 \%$. Given the taste preferences and the high price consciousness of the consumers, it is expected that these three oils will continue to account for the bulk of the edible oil consumption in
India. (FAO Stat)

\section{Materials and Methods}

The district Fatehpur was selected purposively in order to avoid operational inconvenience of investigator. A multistage stratified random cum purposive sampling technique was used for the present study. Out of 13 blocks selected district, one block namely Hathgam was selected randomly for the study. A list of all the villages of selected block was prepared separately along with their area under mustard cultivation. Five villages from this block were selected randomly, i.e. Ajaipur Kondaila, Maupara, Semraha, Ambi and Rajapur. A list of oilseed growers of the five selected villages was prepared along with their size of holdings. Then from this list the farm holdings were categorized into three size groups i.e. marginal (below 1 ha), small (1 to 2 ha.) and medium (2 to 4 ha.) and a sample of hundred respondents were selected using proportionate random sampling technique. The secondary data were collected from published/ unpublished record of district and block headquarters. The primary data were collected through well structured pre - tested schedule of enquiry by interview method during the agricultural year 2015-16.

\section{Analytical tools}

Suitable statistical tools were used for analysis of data. Tabular analysis was used to compare the different parameters among marginal, small and medium size groups of the farmers.

To examine the profitability, the cost of cultivation and returns were worked out on per ha basis. In this computation weighted average were used. Cost of cultivation and returns were estimated using standardized CACP cost concept. 


\section{Weighted average}

The simplest and important measures of average which have been used into statistical analysis were the weighted average. To estimate the weighted average following formula was used:

$$
\mathrm{W} . \mathrm{A} .=\frac{\sum \mathrm{W}_{\mathrm{i}} \mathrm{X}_{\mathrm{i}}}{\sum \mathrm{W}_{\mathrm{i}}}
$$

\section{Where-}

W.A. $=$ Weighted average

$\mathrm{Xi}=$ variable

Wi $=$ Weights of $X_{\mathrm{i}}$

\section{Result and Discussion}

The results to costs and returns, of mustard cultivation have been worked out and are discussed as under.

\section{Costs and returns in mustard cultivation}

Per hectare costs incurred on the various input factor in the production of mustard was worked out and are given in Table 1. It is revealed from the costs of cultivation was highest on medium farms Rs.32555.94 followed by small farms Rs.30223.43 and marginal farms Rs.30099.38. The overall average of costs of cultivation was found to be Rs.30448.01 on sample farms. On an overall average the major component of the cost were human labour (28.29 per cent), rental value of owned land (21.35 per cent), irrigation charge (15.39 per cent), machinery charges (9.03 per cent), manure and fertilizers (7.11 per cent), plant protection (0.71 per cent), interest on working capital (3.24 per cent), seed (2.43 per cent) and interest on fixed capital (1.62 per cent), respectively of the total costs of cultivation. Cost of cultivation of mustard crop, reflect positive relationship with size group of farms, as it was increases with an increase in holding size of sample farm. The major input factors responsible for raising the costs of cultivation were machinery charges and manure and fertilizer with the help of above result presented in table 1 . It is concluded that per hectare costs of cultivation of mustard increases with increase in holding size.

\section{Per hectare costs and income measures from production of Mustard}

The Table 2 revealed that, on an average cost $A_{1} / A_{2}$, cost $B_{1}$, cost $B_{2}$, cost $C_{1}$, cost $C_{2}$ and cost C3 came to Rs.14333.06, Rs.14824.97, Rs. 21324.97, Rs. 21180.01, 27680.01 and Rs. 30448.01, respectively. On overall average, gross income was recorded Rs. 43994.73 and net income came to Rs.13847.75. On marginal farms, gross income was highest, which was recorded Rs.44173.71, followed by small farms Rs. 43861.68 and lowest on medium farms i.e. Rs. 43626.88, respectively. The net income was highest on marginal farms Rs. (14074.33), followed by small farms Rs.(13637.95) and lowest medium farms Rs. (13501.04).On overall average family labour income, farm investment income and farm business income were observed to Rs. 22669.76, Rs. 24814.09 and Rs. 29661.67, respectively. Family labour income was highest on marginal farms followed by small and medium farms and farm investment income was highest on marginal farms followed by small and medium farms and farm business income was highest on marginal farms followed by small farms and medium farms. On an average, cost of production per quintal was estimated to Rs. 2302.65 which was maximum on medium farms i.e. 2479.50 fallowed by small and marginal size of farms i.e. Rs. 2291.38 and Rs. 2268.22, respectively. On an average input output ratio the basis costs $A_{1} / A_{2}, B_{1}$, $\mathrm{C}_{1}, \mathrm{C}_{2}$ and $\mathrm{C}_{3}$ were recorded 1:3.06, 1:2.96, $1: 2.06, \quad 1: 2.07, \quad 1: 1.58$ and 1:1.44, respectively. On the basis of cost $\mathrm{C}_{3}$, the output: input ratio was highest on marginal 
farms i.e. 1:1.46 followed by small and medium size group of farms i.e. 1:1.45 and $1: 1.34$, respectively. It may be concluded from above discussion that marginal farmers were more conscious about economic cultivation of mustard, than the small and medium farmers. Which results in positive association of cost of cultivation and inverse relationship of income measures with size of holding on sample farms.

Table.1 Per hectare costs of different inputs used in Mustard production (Rs.)

\begin{tabular}{|c|c|c|c|c|c|}
\hline \multirow{2}{*}{$\begin{array}{l}\text { S. } \\
\text { No. }\end{array}$} & \multirow[t]{2}{*}{ Particulars } & \multicolumn{4}{|c|}{ Size group of farms } \\
\hline & & Marginal & Small & Medium & $\begin{array}{r}\text { Overall } \\
\text { average }\end{array}$ \\
\hline 1. & Human Labour & $\begin{array}{l}8808.18 \\
(29.26)\end{array}$ & $\begin{array}{l}8241.11 \\
(27.27)\end{array}$ & $\begin{array}{l}8870.95 \\
(27.25)\end{array}$ & $\begin{array}{c}8613.84 \\
(28.29)\end{array}$ \\
\hline a. & Family Labour & $\begin{array}{l}8129.38 \\
(27.01)\end{array}$ & $\begin{array}{l}4678.50 \\
(15.79)\end{array}$ & $\begin{array}{c}3736.55 \\
(11.48)\end{array}$ & $\begin{array}{l}6355.04 \\
(20.87)\end{array}$ \\
\hline b. & Hired Labour & $\begin{array}{l}678.80 \\
(2.26)\end{array}$ & $\begin{array}{l}3562.61 \\
(11.79)\end{array}$ & $\begin{array}{c}5134.40 \\
(15.77)\end{array}$ & $\begin{array}{c}2258.80 \\
(7.42)\end{array}$ \\
\hline 2. & Bullock labour & $\begin{array}{c}1019.74 \\
(3.39)\end{array}$ & $\begin{array}{c}0.00 \\
(0.00)\end{array}$ & $\begin{array}{c}0.00 \\
(0.00)\end{array}$ & $\begin{array}{l}529.91 \\
(1.74)\end{array}$ \\
\hline 2. & Machinery Charges & $\begin{array}{l}2025.00 \\
(6.73)\end{array}$ & $\begin{array}{r}3481.30 \\
(11.52)\end{array}$ & $\begin{array}{c}3682.79 \\
(11.31)\end{array}$ & $\begin{array}{c}2749.50 \\
(9.03)\end{array}$ \\
\hline 3. & Seed & $\begin{array}{l}712.05 \\
(2.37)\end{array}$ & $\begin{array}{c}714.39 \\
(2.36)\end{array}$ & $\begin{array}{r}938.17 \\
(2.88)\end{array}$ & $\begin{array}{c}740.90 \\
(2.43)\end{array}$ \\
\hline 4. & Manure and fertilizer & $\begin{array}{l}2109.23 \\
(7.01)\end{array}$ & $\begin{array}{c}2198.03 \\
(7.27)\end{array}$ & $\begin{array}{c}2311.82 \\
(7.10)\end{array}$ & $\begin{array}{c}2165.99 \\
(7.11)\end{array}$ \\
\hline 5. & Irrigation & $\begin{array}{l}4620.06 \\
(15.35)\end{array}$ & $\begin{array}{l}4626.16 \\
(15.31)\end{array}$ & $\begin{array}{l}5145.16 \\
(15.80)\end{array}$ & $\begin{array}{r}4687.30 \\
(15.39)\end{array}$ \\
\hline 6. & Plant Protection & $\begin{array}{l}140.38 \\
(0.47)\end{array}$ & $\begin{array}{c}218.69 \\
(0.72)\end{array}$ & $\begin{array}{l}521.5 \\
(1.60)\end{array}$ & $\begin{array}{r}215.52 \\
(0.71)\end{array}$ \\
\hline 7. & Total working capital & $\begin{array}{c}19434.64 \\
(64.57)\end{array}$ & $\begin{array}{c}19479.68 \\
(64.45)\end{array}$ & $\begin{array}{c}21470.39 \\
(65.80)\end{array}$ & $\begin{array}{c}19702.96 \\
(64.71)\end{array}$ \\
\hline 8. & $\begin{array}{l}\text { Interest on working } \\
\text { capital }\end{array}$ & $\begin{array}{l}971.73 \\
(3.23)\end{array}$ & $\begin{array}{l}973.98 \\
(3.22)\end{array}$ & $\begin{array}{c}1073.51 \\
(3.30)\end{array}$ & $\begin{array}{l}985.14 \\
(3.24)\end{array}$ \\
\hline 9. & Rental value of land & $\begin{array}{l}6500.00 \\
(21.60)\end{array}$ & $\begin{array}{l}6500.00 \\
(21.51)\end{array}$ & $\begin{array}{l}6500.00 \\
(19.97)\end{array}$ & $\begin{array}{l}6500.00 \\
(21.35)\end{array}$ \\
\hline 10. & $\begin{array}{l}\text { Interest on fixed } \\
\text { capital }\end{array}$ & $\begin{array}{c}456.71 \\
(1.52)\end{array}$ & $\begin{array}{c}522.19 \\
(1.73)\end{array}$ & $\begin{array}{l}552.41 \\
(1.70)\end{array}$ & $\begin{array}{l}491.91 \\
(1.62)\end{array}$ \\
\hline 11. & Sub total & $\begin{array}{c}27363.08 \\
(90.91)\end{array}$ & $\begin{array}{c}27475.85 \\
(90.91)\end{array}$ & $\begin{array}{l}29596.31 \\
(90.91)\end{array}$ & $\begin{array}{l}27680.04 \\
(90.91)\end{array}$ \\
\hline 12. & $\begin{array}{l}\text { Managerial Cost } \\
\text { @ 10\% of sub-total }\end{array}$ & $\begin{array}{l}2736.30 \\
(9.09)\end{array}$ & $\begin{array}{l}2747.58 \\
(9.09)\end{array}$ & $\begin{array}{c}2959.63 \\
(9.09)\end{array}$ & $\begin{array}{c}2768.00 \\
(9.09)\end{array}$ \\
\hline & Grand total & $\begin{array}{l}30099.38 \\
(100)\end{array}$ & $\begin{array}{l}\text { 30223.43 } \\
(100)\end{array}$ & $\begin{array}{l}32555.94 \\
(100)\end{array}$ & $\begin{array}{c}30448.01 \\
(100)\end{array}$ \\
\hline
\end{tabular}

(Figure in parentheses indicate the percentage to total) 
Table.2 Measures of per hectare cost and profit of Mustard (Rs.)

\begin{tabular}{|c|c|c|c|c|c|}
\hline \multirow{2}{*}{$\begin{array}{l}\text { S. } \\
\text { No. }\end{array}$} & \multirow{2}{*}{ Particulars } & \multicolumn{3}{|c|}{ Size group of farms } & \multirow[b]{2}{*}{$\begin{array}{c}\text { Overall } \\
\text { average }\end{array}$} \\
\hline & & Marginal & Small & Medium & \\
\hline 1. & Cost A1/A2 & 12276.99 & 15775.16 & 18807.35 & 14333.06 \\
\hline 2. & Cost B1 & 12733.70 & 16297.35 & 19359.76 & 14824.97 \\
\hline 3. & Cost B2 & 19233.70 & 22797.35 & 25859.76 & 21324.97 \\
\hline 4. & Cost C1 & 20863.08 & 20975.85 & 23096.31 & 21180.01 \\
\hline 5. & Cost C2 & 27363.08 & 27475.85 & 29596.31 & 27680.01 \\
\hline 6. & Cost C3 & 30099.38 & 30223.43 & 32555.94 & 30448.01 \\
\hline 7. & Yield q/ha. & 13.27 & 13.19 & 13.13 & 13.22 \\
\hline 8. & Grass Income & 44173.71 & 43861.68 & 43626.88 & 43994.73 \\
\hline 9. & Net return over cost $\mathrm{C} 3$ & 14074.33 & 13637.95 & 13501.04 & 13847.75 \\
\hline 10. & Family Labour Income & 24940.01 & 21064.33 & 17767.12 & 22669.76 \\
\hline 11. & Farm investment income & 25749.01 & 23903.34 & 23513.08 & 24814.09 \\
\hline 12. & Farm Business income & 31896.72 & 28086.52 & 24819.53 & 29661.67 \\
\hline \multirow{2}{*}{13.} & Cost of production (q/ha.) & & & & \\
\hline & On Cost C3 basis & 2268.22 & 2291.38 & 2479.50 & 2302.65 \\
\hline 14. & Input-Output ratio & & & & \\
\hline a. & On the basis of cost A1 & $1: 3.59$ & $1: 2.78$ & $1: 2.31$ & $1: 3.06$ \\
\hline b. & On the basis of cost B1 & $1: 3.46$ & $1: 2.69$ & $1: 2.25$ & $1: 2.96$ \\
\hline c. & On the basis of cost $\mathrm{B} 2$ & $1: 2.96$ & $1: 1.92$ & $1: 1.68$ & $1: 2.06$ \\
\hline d. & On the basis of cost $\mathrm{C} 1$ & $1: 2.11$ & $1: 2.09$ & $1: 1.88$ & $1: 2.07$ \\
\hline e. & On the basis of cost $\mathrm{C} 2$ & 1:1.61 & $1: 1.59$ & $1: 1.47$ & $1: 1.58$ \\
\hline f. & On the basis of cost $C 3$ & $1: 1.46$ & $1: 1.45$ & $1: 1.34$ & $1: 1.44$ \\
\hline
\end{tabular}

Smarmy and conclusion of the study are as follows:

Cost of cultivation of mustard indicates that it is an input responsive crop. Cost of cultivation was higher on medium size of farms followed by small and marginal size group of farms. It may be concluded that per hectare costs of cultivation of mustard increases with an increase in farm size. On overall average, cost of cultivation per hectare of mustard came to Rs 30448.01. The net income, family labour income, farm investment income, and farm business income were found Rs. 13847.75, Rs 22669.76, Rs 24814.09 and Rs. 29661.67, respectively from mustard crop. It is concluded from the results that various income measures were found in negative relation with size of holding. Due to some unrecorded reasons cost per hectare increased with holding size but sample farmers of all three categories could receive the equal yield. Which reversed the relationship of costs and income with size of holdings respectively.

\section{References}

Gautam D.S. (1993) "Profit structure of bajra, wheat and rapeseed/ mustard cultivation in central India." Indian journal of Agricultural Research: 1999. 33:3,171177

Gawaria, K. M. Gajja, B. L. Sharma, S. B. (2011). "Economic efficiency of mustard production in arid region of 
Rajasthan: an econometric analysis."

Banaras Hindu University - CAB Abstracts Current Agriculture; 2011. 35(1/2):27-32.

Kumar, P. Barman, R.N. Dhaka, J.M. (1997) "Rapeseed and mustard production in Rajasthan: a study of instability and factor of production." Annual of Biology (Ludhiana):1997. 13:1, 207-211

Lashari, M. I. Khushk, A. M (2004). "Economics of rapeseed and mustard cultivation in Sindh." Indus Journal of Plant Sciences; 2004. 3(4):409- 416.

Patil, S.M. (1995). Yield Gaps and Constraints in Groundnut production in Karnataka. An Economic Analysis. M.Sc. (Agri.) Thesis, University of Agricultural Sciences, Dharwad. $i$ Povrtarstvo; 47(1):179-185.

Ruza, L. (2009) "Assessment of rapeseed production in the regions of Latvia and farms of different size." (Economic Science for Rural Development, No.20) Finances, taxes, investment and support systems. Proceedings of the International Scientific Conference, 2324 April, 167-173.

Samarthia, T. T. (1999). "Oilseed production patterns in India." Banaras Hindu University - CAB Abstracts Anvesak; 1999. 29(1):27-42.

Singh O.P. (2002). "An analysis of major oilseeds production in Gujarat, India." Banaras Hindu University - $C A B$ Abstracts Economic Affairs (Calcutta); 2002. 47(4):234-243.

Singh, G. Chandra, H. (2004). "Growth analysis of production and economic factors in rapeseed-mustard cultivation in India." Journal of Oilseeds Research; 21(1):125-129.

\section{How to cite this article:}

Praveen Kumar Sahu, Krishna Kant, Harendra Pratap Singh Choudhri and Singh, G.P. 2018. Cost of Cultivation of Mustard crop in Fatehpur District of Uttar Pradesh. Int.J.Curr.Microbiol.App.Sci. 7(08): 3356-3361. doi: https://doi.org/10.20546/ijcmas.2018.708.359 